\title{
FROM ACTION RESEARCH TO PRACTICE RESEARCH
}

Göran Goldkuhl

Linköping university

goran.goldkuhl@liu.se

\begin{abstract}
Action research (AR) has gained more acceptance as an approach to qualitative research in information systems (IS). The complexities of organisational and technical change makes this approach a suitable one in IS research. There are, however, still some controversies and confusions about the relation between "action" and "research". The many types of AR and similar approaches (not labelled as AR) that have emerged demand further conceptual clarification of AR. A conceptual inquiry of AR, presented in the paper, has led to the identification of several unresolved issues concerning intervention research like AR. An alternative research approach is presented: practice research. This research approach is well founded in pragmatism and it is founded on the two premises: 1) to contribute to general practice through abstract and useful knowledge and 2) to study the empirical field as interconnected practices. Several important concepts of practice research are described as: local practice contribution vs. general practice contribution; theorizing vs. situational inquiry; abstract vs. situational knowledge. These notions and their pragmatist foundations can help to sharpen AR as a qualitative research approach. Practice research is defined as a broader notion encompassing AR and other research approaches as e.g. design research and evaluation research. Two case examples of practice research are briefly presented and compared: one AR-based study in the social welfare sector and one evaluation study of a taxation e-service.
\end{abstract}

\section{INTRODUCTION}

Action research (AR) has evolved as an important approach of qualitative research within information systems (IS). There seems to still be many sceptics, but the acceptance and prestige of this research approach is growing. The two special issues in Information Technology \& People (Kock \& Lau, 2001) and MIS Quarterly (Baskerville \& Myers, 2004), together with the compilation of articles in Kock (2006), are signs of this growing recognition. Action research has indeed strengthened qualitative research in IS with its specific qualities of closeness to the empirical field, exploration of change and ensuring practical relevance. AR seems to be especially appropriate in the IS area since we are so concerned with issues of organisational, informational and technical change. Since AR deviates from classical scientific endeavours in several ways, there have been several efforts to clarify the scientific character of AR. There are many examples of this, such as classical ones like e.g. Rapoport (1970), Susman \& Evered (1978) and Hult \& Lennung (1980) and specific IS efforts like e.g. Checkland (1991), Baskerville (1999), McKay \& Marshall (2001), Davison et al (2004). One core issue has been the relation between action and research. Several scholars have tried to clarify how research and problem solving interests intersect and interact (Marshall \& McKay, 2001; Davison et al, 2004).

What we call action research is, however, not the only research approach that deals with intervention in practice. There are several other research approaches that include intervention and collaboration 
with practitioners; e.g. action science (Argyris et al, 1985), action learning (Revans, 1982), interactive research (Lundin \& Wirdenius, 1990), participative research (Elden, 1983), participatory research (Parks, 2001), participative case study (Baskerville, 1997), collaborative practice research (Mathiassen, 2002), collaborative management research (Pasmore et al, 2008), co-operative inquiry (Heron \& Reason, 2001), clinical inquiry (Schein, 2001), development action inquiry (Torbert, 1999), appreciative inquiry (Ludema et al, 2001), pragmatic-systemic inquiry (Cronen, 2001), practical inquiry (Stevenson, 2005; Goldkuhl, 2008) and pragmatic inquiry (Metcalfe, 2008). This means that there are complementary views that have not found their place within approaches called action research, although several of the approaches mentioned above are sometimes seen as variants of action research. There are needs for further investigation of action research and other intervention approaches. How should we conceptualise such approaches? What criteria exist for making them scientific? Sometimes AR is confused with plain consulting and it is therefore important to state criteria for what makes AR scientific and distinguishable from consulting although some similarities exist (Gummesson, 1988; Baskerville, 1997). There is also a growing debate within IS about the relations, similarities and differences between AR and design research (e.g. Cole et al, 2005; Järvinen, 2005; Iivari \& Venable, 2009; Sein et al, 2011). In order to clarify how AR and design research relate to each other it is necessary to have a clear conceptual image of AR.

It is also the case that AR has over the years been diversified in a large number of variants (Baskerville \& Wood-Harper, 1998; Casell \& Johnsson, 2006; Chandler \& Torbert, 2003; Lau, 1997). Reason (1999, p 222) is drastic concerning implications of this diversification: "My experience of the term 'action research' is that it means so many things to so many people that it is methodologically useless to distinguish one strategy from another". I would definitely not go so far as to state that the term 'action research' has lost its meaning and become useless. It is in good use, but there seems to be a need for further conceptual clarification concerning its characteristics and limits.

The paradigmatic foundations of AR are not always clear. In many accounts of AR there are no explicit references to any paradigm or scientific school of thought. One typical example is Braa \& Vidgen (1999), who have stated an IS research framework through comparison of three different research approaches (prediction/reduction, interpretation/understanding, intervention/change). Two of them have been positioned paradigmatically in clear ways (prediction/reduction as positivism; interpretation/understanding as interpretivism), but the third one (intervention/change) has no identified paradigmatic home. However, there exist clear accounts of the epistemological basis for AR. Baskerville \& Myers (2004) have clearly positioned AR within pragmatism; cf. also Oquist (1978). The full consequences of this paradigmatic positioning are, however, still to be found.

The overall purpose of this paper is to investigate intervention-oriented strategies that are relevant in qualitative research on information systems and organisations. It is natural and appropriate to take the point of departure in action research. This inquiry on AR will focus

- "action", i.e. the problem solving and how it is constituted as a part of the research process

- "research", i.e. what makes AR scientific (the research legitimacy of AR).

Through this inquiry a number of AR issues emerge that comprise controversies, obscurities or are unresolved in other ways. This inquiry and its identification of important issues have informed the articulation of a partially alternative qualitative research approach. This alternative approach will be labelled practice research (PR). The articulation of practice research implies also a clarification of AR as a viable research orientation. The formulation of practice research should not at all be interpreted as a rejection of $\mathrm{AR}$ as an appropriate research approach for qualitative research in IS. AR has important qualities which should be acknowledged and defended. However, as the discourses on AR indicate, there are needs for clarification and this paper contributes with some clarification of such a kind. 
The conceptual development of PR is illustrated by two case studies in e-government. One study is an evaluation of a taxation e-service. The other one is an action research study comprising development of an IT artefact for information-transfer between state agencies and municipal welfare offices. The two case studies are compared in relation to action research and practice research. This also means that this paper uses a combined approach of conceptual inquiry and empirical case studies in order to formulate its contributions.

To summarize the purposes of this paper: It contributes with

- knowledge about important unresolved issues concerning action research (and other intervention strategies) that need clarification

- an articulation of an alternative research approach, "practice research", based on the AR inquiry that includes the formulation of several concepts and dualities and a pragmatist foundation

- a comparative clarification of action research and practice research and relations between these approaches

- a partial reformulation of action research based on practice research notions

\section{ACTION AND RESEARCH IN ACTION RESEARCH: A CONCEPTUAL INQUIRY}

The main knowledge interest in this inquiry has been on "action" and "research" in AR; i.e. issues of intervention, collaboration and what makes AR scientific and other related questions. In order to identify and investigate such issues a literature review has been conducted. Important publications on AR in IS and generally on AR have been studied. Different themes have been identified based on the main knowledge interest during the review of the literature. It has been important to disclose alternative views within these themes. This search for alternative views has also guided the selection of literature. This investigation has been labelled a conceptual inquiry, which means that it has been guided by an interest for improvement and clarification.

\section{Goals and target groups}

Action research deviates from classical research in several ways. This makes it necessary to make a proper conceptualisation of what is done in AR (McKay \& Marshall, 2001; Davison et al, 2004). One key feature of AR is serving "two masters" (Kock \& Lau, 2001). AR is aiming to contribute both to a research community and to practitioners in a specific problematic situation according to classical definitions by Rapoport (1970) and Hult \& Lennung (1980). This is expressed in the following way by Rapoport (1970): "Action research aims to contribute both to the practical concerns of people in an immediate problematic situation and to the goals of social science by joint collaboration within a mutually acceptable ethical framework". This definition includes the conjoint goals of action research; that of practical problem solving and contribution to scientific knowledge. It is notable that Rapoport talks about "an immediate problematic situation", which means that general practical relevance is not explicitly considered. A more elaborated definition, but still in the same spirit, is formulated by Hult \& Lennung (1980). They have reviewed an extensive amount of literature in AR and refined the definition from Rapoport. In their definition, the practical goals and procedures in action research are elaborated, but not the ones concerning scientific knowledge. Hult \& Lennung emphasise collaboration, mutual learning and local understanding, which are goals often referred to in AR. The goals of scientific results, i.e. the contribution to the scientific body of knowledge are not problematized. The character of the scientific contribution is simply taken for granted. The main target groups of AR seem to be the people in the local operational practice and the scientific community. Other practitioners outside the local operational practice do not seem to be a specified target group. There has actually been critique against AR from the perspective of improved practical relevance of IS research. If the results from an AR project are too specific concerning its problems of that specific company, these results are not considered to be practically relevant in a general a sense. 
There seems, however, to be a misconception, that generalizable results need to be stated in terms of practical problems solved. Nielsen (2007) has argued for a transferability criteria in AR (instead of generalizability). It is claimed that "we need to explicate the general characteristics of the findings and the conditions for transferring them to other situations" (ibid 365).

\section{Dual processes working in cycles}

This dual purpose has led McKay \& Marshall $(2001 ; 2002 ; 2006)$ to describe AR in terms of two interrelated process cycles. There is one problem solving cycle that describes the problem solving process and there is one research cycle that describes the management of the research interests. These cycles are described in a similar generic way (figure 1) consisting of some initial steps and then a cycle of steps that can be pursued until a satisfactory result is reached.

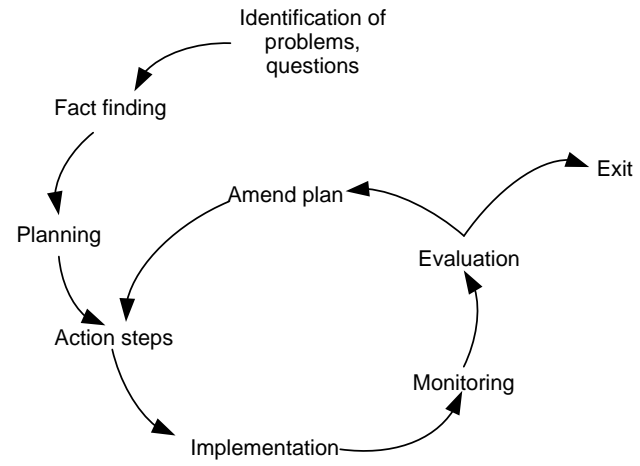

Figure $1 \mathrm{~A}$ generic process cycle for problem solving and research in AR (based on McKay \& Marshall, 2001)

First, it is important to note that this cycle deviates from the classical AR cycle in Susman \& Evered (1978); cf. figure 2. Problem analysis and diagnosis are in the process of McKay \& Marshall left out from the cycle and defined as an introductory step that is not iterated. It is hard to see any reasons for eliminating the diagnosis/problem analysis from the iterative cycle. Later work with implementation can give rise to needs in order to better understand the original problem-situation.

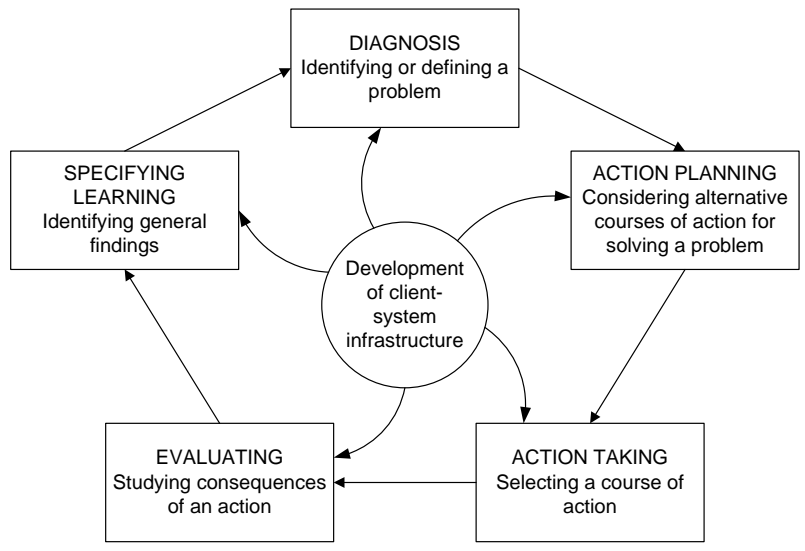

Figure 2 A classical cycle description of action research (from Susman \& Evered, 1978)

There are several other problematic issues in this dual cycle conceptualisation of AR. The two process cycles are described as working in tandem. They are superimposed upon each other. What this exactly 
means is not clarified. In a later paper (McKay \& Marshall, 2002) the two processes are described in an integrated way, but this still leaves questions with regard to how the two cycles work in tandem. For example, are there actions that are multi-functional and thus belong to both cycles? Are there other actions that only belong to one cycle? Should it not be necessary to clearly describe what actions belong to a single cycle and what actions belong to both cycles?

The problem solving cycle is described from the researcher's perspective. "The first cycle relates to the researcher's problem solving interests and responsibilities..." (McKay \& Marshall, 2001, p 50). Why is this not done from the problem owner's perspective? Would that not be more adequate? The research cycle does not seem to be properly described. Where is data collection, data analysis and theory development performed in the research process cycle? Is it so that the (implicit) aim to describe the two processes in a similar way (based on a generic process structure) has hampered the formulation of adapted process descriptions? A generic structure has, in an obtrusive way, been imposed on to the two processes of problem solving and research. We should rather try to understand each process and then try to integrate them in a proper way.

An alternative conceptualisation will be presented as a way to resolve this obscurity. The research process is divided into two fundamental activities of theoretical and empirical work (figure 3 ). This division is valid for action research and for all other types of research that is empirical in nature. There is a difference between action research and more classical empirical research that cycling between theorizing and empirical investigation is much more intense in AR. In a classical research approach there will be an initial theoretical part with hypothesis formulation and preparation of investigation and then a gathering of data followed by concluding analysis of data. There will be just one cycle; first theory, then empirics and then back to theory. In an action research context there will be many movements back and forth between theory and empirics. This is also the case for most qualitative research approaches; see e.g. descriptions of Grounded Theory (e.g. Strauss \& Corbin, 1998) where a continual interplay between data collection and data analysis is prescribed.

What are the corresponding fundamental constituents of practical problem solving? The generic structure (from McKay \& Marshall, 2001) seems to be more adapted to problem solving than research so it would be more appropriate to use this structure here than for research. However, is it possible to boil down practical problem solving and change into two fundamental activities? Practical problem solving originates from some problems in operational work. These problems give rise to a developmental process followed by implementation of changes into the operational practice. We can describe practical problem solving as a movement from operational work to developmental work and then back to operational work (figure 4).

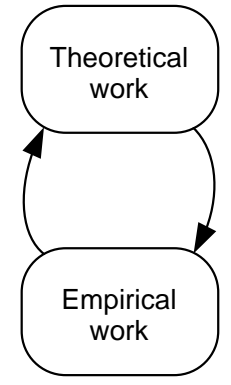

Figure 3 Research process cycle

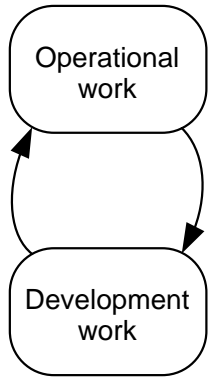

Figure 4 Problem solving cycle

Described in this way, there is a one-cycle movement like in classical research; first operation, then development, then implementation which means back to operation. There might be other types of 
change processes (like experimental, incremental and agile approaches) that work with many small cycles going back and forth between operational and developmental work.

If we take these two cycles and use them as a lens when looking at AR, what can be seen? Can we put the two cycles on top of each other? AR works with practical problem solving. The researchers' work together with practitioners to develop some operational practice is empirical work when looking at it from a research perspective. From the practitioners' perspective this is researcher involvement in their development work. This implies that developmental and empirical work may coincide to a large degree. What is done in a collaboration process between researchers and practitioners is at the same time both 1) development of a local operational practice and 2) empirical research. This follows from the dual purposes of AR. This means that action research can be described in terms of the interrelatedness of three practices (Cronholm \& Goldkuhl, 2004): 1) Theoretical work, 2) empirical and developmental work and 3) operational work (figure 5). The operational work is the object of problem solving, development and change.

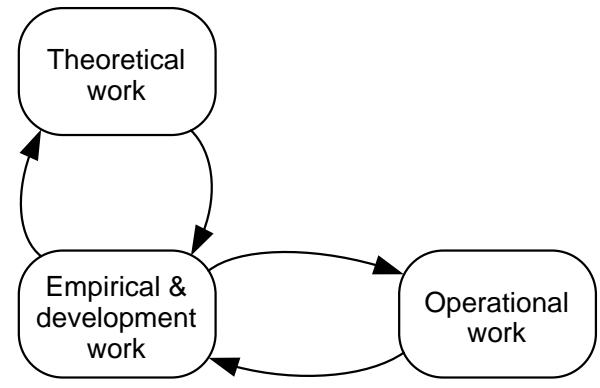

Figure 5 Integration of research and practical problem solving

It should be noted that development and empirical work do not fully coincide (Goldkuhl, 2011). There may be empirical data collection made by researchers (in AR projects) that is mainly done in the service of theorizing (i.e. empirical work separated from development). There will also be development work performed by the practitioners that lies outside the interest of the researchers (i.e. development work outside the object of empirical research).

\section{Research interest vs. problem solving interest}

Albeit conceptual problems in the dual cycle model, McKay \& Marshall (2001, 2002) have contributed with an in-depth analysis of problem solving vs. research interest in AR. Peters \& Robinson (1984) have in a survey study of AR identified that there does not seem to be consensus what interest should have the privilege over the other. This has been described as a classical dilemma in action research (Rapoport, 1970). There may be a risk to be too compliant to practitioners' problem definitions. These can be unreflective and block an unbiased inquiry. On the contrary Schein (2001) makes strong claims in his clinical approach that the inquiry process should be guided by the practical problems. "It is my argument that some of the best opportunities for such an inquiry actually arise in situations where the setting is created by someone who wants help, not by the researcher deciding what to study" (ibid p 228).

\section{The issue of practical relevance}

To have a practical problem solving interest governing the research process, as in AR, is a way to respond to the demands for more practical relevance in IS research (Baskerville \& Myers, 2004; Davison et al, 2004). There has been a long debate on practical relevance in IS research and its relations to research rigour (e.g. Keen, 1991; Benbasat \& Zmud, 1999; Davenport \& Markus, 1999; Lee, 1999; Lyytinen, 1999). Relevance has been divided into several dimensions. Benbasat \& Zmud 
(1999) have made a division into interesting and current (timely) topic, applicable results and accessible and readable publications. This division has been used by other scholars with some slight conceptual/terminological modification. Klein et al (2006) speak of relevance in terms of importance, applicability and accessibility and Rosemann \& Vessey (2008) use the terms importance, suitability and accessibility. Relevance can be seen as an issue of input to research (selection of an important topic) and output from research (production of useful results). AR has important methodological features for warranting both input relevance and output usefulness. The selection of a practical problem to be solved (i.e. a problem solving interest) is a way to ensure a selected topic of relevance. However, objections may be raised against this. Something that is of concern in one organisation might not be of concern to many other organisations. To be responsive to one single organisation does not ensure a broad practical importance of the topic selected.

There are other issues concerning the relevance of input than of topic selection. After selecting a relevant topic you need data that is relevant to this topic. An AR endeavour works usually with data generation of in-depth character and over a long time-span. This is a way to ensure a nuanced body of data as a basis for theoretical generation. For example, Lyytinen (1999) pinpoints the need for close cooperation with practitioners on a long-term basis to ensure relevance.

One demand in action research is the search for a workable change in the client-organisation. To have a solution that works in at least one organisation is a way to ensure some applicability of results. However, criticism can also be raised that this is a narrow application. Here, the idea of viewing research in terms of inquiry in the professions (Davenport \& Markus, 1999; Lee, 1999) seems adequate as a response. This implies formulation of abstract knowledge of professional value and use.

\section{Empirical vs. theoretical activities}

The structure of AR into five phases as described by Susman \& Evered (1978) - see figure 2 - has according to Davison et al (2004) reached a canonical status. This means that action researchers should adhere to this structure (ibid.), otherwise clear reasons should be stated. The main parts of this structure follow principles of developmental work (diagnosis, planning, implementation, evaluation). This means that these activities are clearly empirical in nature. The fifth activity, originally labelled "specifying learning", is not very clear in the original text of Susman \& Evered (1978). It is only further specified as "identifying general findings" (ibid p 588). Davison et al (2004) have contributed with more substance to this phase. From their description, it is obvious that this activity (here labelled "reflection and learning") contains theorizing parts. They specify requirements for this phase as "informing/re-informing theory" (ibid p 77).

The place as the last phase in the AR phase model (figure 2) thus seems to be inadequate. A key feature of many AR projects is the continual interplay between empirical and theoretical work. Researchers will now and then reflect and analyse the different findings. Theorizing (reflection and learning) will not only be the last phase in AR. It will run in continual parallel with diagnosis, planning, implementation and evaluation. The description of these empirical and theoretical activities should rather be performed following the principal structure of figure 5.

The canonical AR model by Susman \& Evered (1978) can be seen to be refinement of earlier AR models. In his original description of AR Kurt Lewin (1947) made a division into three phases: 1) investigation of the initial situation, 2) intervention, 3) investigation of the resulting situation. In another classical article, Blum (1955) made a division into two stages: 1) a diagnostic stage and, 2) a therapeutic stage. The logic of all these accounts is the solving of a practical problem. There is no or little emphasis of the role of theorizing activities. In order to find an interplay between a practice problem focus and a theoretical reflection we need to move further back to another model of integrated practical problem solving and knowledge production: The inquiry model by Dewey (1938). 
In this model (cf. also Cronen, 2001) there is an explicit inclusion of theorizing activities. This will be further discussed below when articulating practice research.

\section{The role of theory}

How is the researcher informed by theory and other kinds of pre-knowledge in the AR process? There does not seem to be a unanimous view of this matter (Lau, 1997). Davison et al (2004) state the "principle of theory" including arguments for an active use of theory in the AR process. They explicitly state that "action researchers need to rely on one or more theories to guide and focus their activities" (ibid p 74). This is also a key argument in Checkland (1991 p 397) who claims that "there must be an intellectual framework, declared in advance, in terms of which learning will be defined. Without such a framework action research can quickly be indistinguishable from mere action". There are however other views. Elden \& Crisholm (1993 p 127) claim that "the usual theory to practice sequence for formulating research is reversed" in AR with direct reference to Dewey's (1938) thesis of a problematic situation as a trigger to inquiry. Baskerville \& Pries-Heje (1999) has described an AR approach using grounded theory (Strauss \& Corbin, 1998); cf. also Cassell \& Johnsson (2006) for inductive AR practices. An inductive generation of theory implies a minimum use of pre-categories from extant theories. This is to be contrasted to the statement that "a clearly articulated theoretical framework must be imposed on the phenomenon of interest" (Davison et al, 2004 p 73). Mumford (2001) makes claims of both using extant theory and producing theory in new areas.

It is also important to recognise that there are different types of knowledge that are used and generated during AR. Besides abstract theories there will be a use of local and situational knowledge and development of enhancing such knowledge through the AR process. Some scholars talk about development of "local theories" (e.g. Elden, 1983; Israel et al, 1992) when creating a new diagnostic understanding of the local practice.

\section{How to conceive the empirical field}

AR means research into a social setting. It is not research in a reductionist fashion on pre-structured and fixed variables. AR means studying a contextual whole in order to discover and reveal unknown phenomena, properties and relations. Although not always labelled so, AR endeavours are intervention oriented case studies; cf. Vidgen \& Braa (1997) on "action case approaches". Holism is a basic stance in many AR studies. There are scholars making claims to study phenomena in relation to its surrounding environment (e.g. Hult \& Lennung, 1980; Davison et al, 2004). There is however not much discussion on what this means ontologically for inquiries. What is actually meant by context, environment or surrounding? Kemmis \& McTaggart (2000) discuss different extensions of the studied practice; from a more individual level (focus on human actions) to a social level (focus on social interaction). There are some remaining questions: How should we conceive the empirical field? What should govern the inclusion of studied phenomena?

\section{Interaction and collaboration}

How is the interaction between researchers and practitioners conducted? The collaborative nature of $\mathrm{AR}$ is nearly always seen as a key feature. The collaboration can however be pursued in different ways. There are scholars who prefer the term participatory action research (e.g. Kemmis \& McTaggart, 2000) in order to emphasise the collaborative nature of the AR process; how practitioners participate in research. There are some scholars (e.g. Heron \& Reason, 2001) who claim that all decisions, even about clear research matters like method choice should be made by researchers and practitioners together. The practitioners should rather be seen as co-researchers. This can be contrasted with how McKay \& Marshall (2001) describe the separated researcher-based research interest. Davison et al (2004 p 73) describe diagnosis as the first part of AR in the following way: "the researcher has a responsibility to conduct an independent diagnosis not only so as to confirm the 
nature of the problem(s), but also to determine its/their causes". The collaboration seems to be weak in such an independent diagnosis. Huxham \& Vangen (2003 p 385) take a clear instrumental view on collaboration with practitioners. They state that "The concerns to do with empowerment, participation, or learning ... are therefore not regarded as important unless they happen to be connected with the research or action agendas". In a review of different reports of AR endeavours, Avison et al (2001) conclude that there is a great variation in how collaboration between researchers and practitioners is accomplished.

\section{Scientific issues for clarifying action research and other intervention approaches}

This conceptual inquiry has led to the formulation of a number of issues that needs to be dealt with in order to clarify AR. The following issues have been identified:

- The issue of contribution; to whom (research community vs. local practice vs. practice community), what kind of contributions (practical vs. scientific) and how contributions are generated

- The issue of interests and topics; research interest vs. local problem solving interest vs. broader practical interest/importance

- The issue of research activities; what kinds of activities and relations between them, what kinds of underlying conceptualisations of these activities

- The issue of use of pre-knowledge in research; inductive knowledge generation vs. active use of extant theories

- The issue of different types of knowledge and their functions; e.g. local/empirical knowledge vs. theoretical knowledge

- The issue of how to conceive the field of study; conceptions of wholes (holism) vs. conceptions of fragments (atomism)

- The issue of interaction with those researched about; the need for collaboration between researchers and practitioners

- The issue of different research approaches; how AR is related to other research approaches

These issues will guide the further development and clarification of research approaches below. This list should not be seen as exhaustive concerning unresolved AR issues. A deeper literature review might reveal more issues. The claim is that the list covers important issues from the AR discourse within IS. I will explicitly return to these issues when comparing action research and practice research below; cf. especially table 1 .

\section{ARTICULATING PRACTICE RESEARCH}

The investigation of AR above has been a generative force to articulate the paradigm of practice research (PR). The identified issues will be used to clarify the core elements of PR and also to compare the two research orientations.

\section{Practice research as a pragmatic research approach}

Practice research is based on some essential assumptions. The issue of contribution is fundamental. For whom is something being done? What is done for someone? The basic attitude from pragmatism to improve existence through knowledge (Dewey, 1938) is the key motivator. The creation of abstract and useful knowledge for practice communities is seen as the main purpose. This means that practice communities (or what will be called general practice below) are seen as a main target group. There is a second basic assumption complementing this issue of contribution. It concerns the character of empirical field. The notion of practice is here essential. In IS and other related disciplines we should study practices. This means that we should acknowledge the practice character of the empirical field. 
What is done in the design of IT artefacts and when using such artefacts will always be parts of human and social practices. This follows what is sometimes called the practice turn in science (e.g. Schatzki 1996; Schatzki et al, 2001; Gherardi, 2000, 2009; Scollon, 2001; Reckwitz, 2002; Whittington, 2006; Miettinen et al, 2009; Goldkuhl, 2011). A practice is seen as a meaningful and coherent assemblage of human actors, actions, utterances and documents, and material artefacts. Practices are often arranged with purposes to serve other actors outside the practice itself. A practice is shaped by humans as an organised, artificial and continually evolving arrangement, enabled and restricted by human knowledge and financial, semiotic and material conditions. Practice is thus a holistic notion. It avoids however the danger of reification in holistic approaches (e.g. Cuff \& Payne, 1979; Goldkuhl \& Röstlinger, 2002) when acknowledging a practice's basic constituents of human actors, their actions and action objects of semiotic and material character. This makes it possible, when studying practices to move back and forth between the holistic level of the practice and the micro elements of such a practice. This is thus an application of the well-known principle of the hermeneutic circle; a continual shifting between viewing the whole and viewing its parts (Bleicher, 1980). The practice notion has also been acknowledged in IS research; for example in contributions by Orlikowski (2000), Levina \& Vaast (2006), Goldkuhl (2008; 2011) and Gregor (2008).

A key contribution from PR is, as stated above, abstract and useful knowledge for general practice; i.e. a general practice contribution (GPC). There are other target groups of practice research: research community and local practice. PR contributes with abstract knowledge as additions to the scientific body of knowledge (SBK). A main function of the research communities in relation to proposed new additions to SBK is quality assurance through review and dialogue. The research community has a responsibility for the accumulation and dissemination of knowledge generated through research.

Practice research means research on and for practices and will often be research conducted in (or close to) practices. In order to understand and reveal the internal meaning and logic of a practice it will be necessary to be close to the practice and to get access to what is not immediately visible or reportable (Gummesson, 1991). In PR there is an interest for what is actually going in studied practices, not only what people think is happening or should happen (Argyris et al, 1985). In most cases, practice research will contribute to studied local practices. There may be different local practice contributions (LPC) as diagnosis results, design/change proposals and participation in implementation of real practice changes which may include the furnishing of changed or new artefacts (Goldkuhl, 2008; 2011). In AR there is a generation of diagnosis results, design proposals (from action planning) and the implementation of changes (action taking) and evaluation of implemented changes. This follows the canonical AR model (Susman \& Evered, 1978; Davison et al, 2004); cf. figure 2 above. All these four types of results count as LPC. In AR, following the demands of canonical AR (ibid), it is necessary to produce all four types. In practice research, one or several of these local practice contributions can be generated. It is not mandatory to create local changes through such research. In PR it is necessary to produce knowledge of practical value following the ideals of pragmatic inquiry (Dewey, 1938). This means aiming for knowledge that is useful for general practice. The ideal of PR is to strive for inquiry topics that are relevant to both local and general practice and for situational knowledge that is useful for local practice and abstract knowledge that is useful for general practice.

The research work directly related to local practices is called situational inquiry (Goldkuhl, 2011). It is empirical research and it will be driven by a concern for the local practice. As an inquiry, this kind of activity contains a knowledge interest that is guided by a problematic situation and a need to resolve this problematic (indeterminate) situation into a resolved determinate situation (Dewey, 1938). 
The problematic situation that drives the inquiry is located in the local practice, otherwise the local practice should not be used as catalyst for inquiry and knowledge development. However, the comprehension of the problematic situation can in some cases mainly be framed by the researcher's interest for knowledge development, i.e. an inquiry mainly guided by research interests. This research interest can of course be determined by an analysis of gaps in the scientific body of knowledge, but it can also be influenced by knowledge needs apprehended in practitioner communities (general practice needs). However, in many cases the problematic situation emerges directly from the local operational practice and will be encountered as such by its the ordinary members. This will drive the need for inquiry and possible changes. The role of the researchers will then be to take part in this inquiry process as knowledge resources. They will address the problematic situations in the local practices, but they may also add other inquiry drivers based on specific research interests. This relates to the division into problem solving interest and research interest discussed above. Confer Chiasson et al (2009) for an analysis of how research interest vs. problem solving interest can guide the inquiry process.

PR is based on a differentiation into theorizing and empirical work following figure 5 above; cf. Goldkuhl (2008; 2011). It also based on a differentiation between operational practice and its development (figure 4 and 5). A more enhanced model describing practice research in its context is found in figure 6 . The empirical and developmental work is conducted as a situational inquiry. What is done in a situational inquiry is instrumental in relation to theorizing and the creation of abstract knowledge for research and practice communities. Situational inquiry (which may be driven by a practical problem solving interest) is generative for researchers' theorizing.

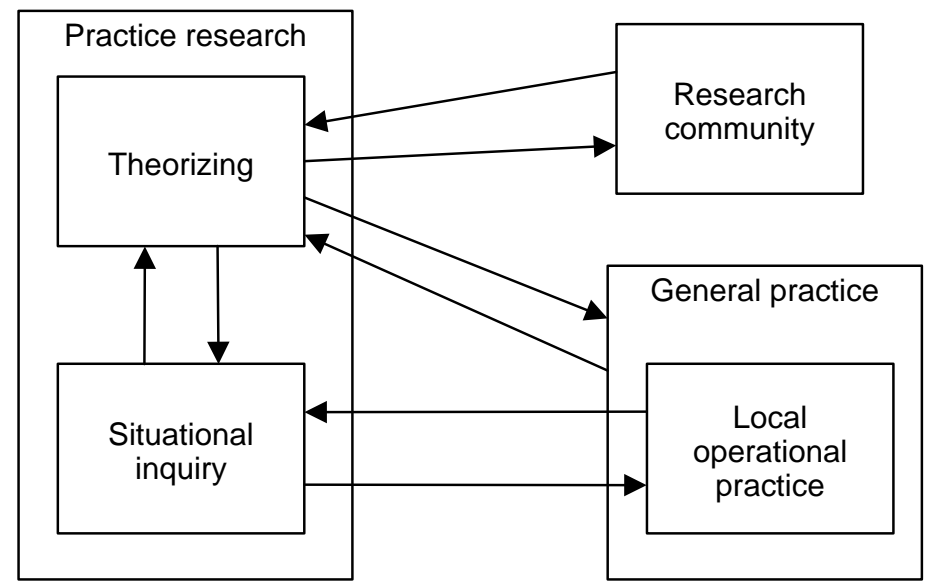

Figure 6 Practice research in context (based on Goldkuhl, 2011)

From the perspective of the local practice, situational inquiry functions as an arena for practical problem solving. The situational inquiry generates situational knowledge for the sake of the local operational practice. From the perspective of practice research and theorizing, the situational inquiry functions as a generator of empirical data and an arena for tests and trials of ideas and hypotheses. Theorizing (in practice research) generates abstract knowledge in order to generalise findings and make them transferable to other practice contexts as well as additions to the knowledge base in the research community. This abstract knowledge, can during an on-going situational inquiry, be used as instruments for data collection and practical problem solving. The situational inquiry will in such cases be conducted in a theory-informed way. The used theories in the inquiry can be emergent 
(generated during theorizing working in parallel with the situational inquiry) or can be extant from the knowledge base of the research community. After the empirical work (the situational inquiry) has been terminated, theorizing further refines the abstract knowledge aimed for research and practice communities.

How a situational inquiry is conducted will always be a synthesis and continual balancing of problem solving interests (of local practice) and research interests. There may be more or less use of abstract pre-knowledge. How and when abstract knowledge is generated is also dependent on the combinations of these different interests. There may be use of pre-existing practical theories in situational inquiries (Cronen, 2001; Goldkuhl, 2008). Such pre-knowledge can guide the inquiry process and make it theory-informed. There can also be reasons to test a certain theory, as its practical applicability and/or some hypothetical constructs.

A situational inquiry is performed by researchers. Practitioners can be more or less active in situational inquiries. There may be situational inquiries driven by researchers with a low degree of participation from practitioners. Sometimes practitioners want an independent view from outside investigators. A design proposal may be requested for delivery by independent researchers-asdesigners. There may be other situations with full collaboration between researchers and practitioners. The degree of participation and collaboration is dependent on the purpose of the inquiry, the research interests and the type of intervention asked for by the practitioners. There are many good reasons for a close and active collaboration between researchers and practitioners. There may, however, be resource reasons, knowledge reasons or other reasons against active collaboration.

\section{Action research in the light of practice research}

As can be read from the above description of PR, there are many resemblances between AR and PR. As a matter of fact, AR can be seen as a special kind of practice research. There are some differences both in view and properties which need to be emphasised. A comparison can be found in table 1 . The articulation of practice research has been driven by both the identified needs for clarification of AR and ideas not sufficiently elaborated in AR. There are issues that are not dealt with in ordinary AR, as for example the ontology of the field of study. PR is based on an explicit view on the empirical field as consisting of a set of interrelated practices. Such an explicit stance is not found in AR, although AR studies may adopt a view of this kind. The purpose to contributing to general practice in PR is not stated in AR (Goldkuhl, 2008).

PR avoids the hard and definitive demands on how the research process should be performed (high collaboration, implementation of changes) in AR. Instead, the research design should be adapted to how the research interests and local practice interests can be combined in a constructive and generative way. PR has contributed with important clarifications which are also needed for further conceptualisation of AR:

- Activities: theorizing vs. situational inquiry

- Knowledge: situational knowledge vs. abstract knowledge

- Practices: local vs. general practice

These categories should be used, not only when describing PR, but also in order to clarify AR. A refined model of AR, based on the PR conceptualisation, is found in figure 7. It is important to clearly distinguish between the theoretical work and the empirical work (that is performed mainly through a situational inquiry). The canonical AR cycle (Susman \& Evered, 1978; Davison et al, 2004) should be re-structured. Reflective learning (theorizing) should not be seen as the last activity in a linear cycle. It should rather be seen as a continual activity working in tandem with the different developmental and empirical activities of situational inquiry (figure 7). It is thus important to distinguish between situational knowledge that is generated in situational inquiries and abstract knowledge that is generated through theorizing. 


\begin{tabular}{|c|c|c|}
\hline & Practice research & Action research \\
\hline Main idea & $\begin{array}{l}\text { Production of useful knowledge for } \\
\text { general practice. }\end{array}$ & $\begin{array}{l}\text { Research through local } \\
\text { changes. }\end{array}$ \\
\hline $\begin{array}{l}\text { Contribution } \\
\text { and target } \\
\text { groups }\end{array}$ & $\begin{array}{l}\text { Contribution of abstract knowledge to } \\
\text { general practice and research } \\
\text { community. Situational contribution to } \\
\text { local operational practices. }\end{array}$ & $\begin{array}{l}\text { Problem solving contribution to } \\
\text { local practices and scientific } \\
\text { knowledge to research } \\
\text { community. }\end{array}$ \\
\hline $\begin{array}{l}\text { Conceptualisati } \\
\text { on of research } \\
\text { activities }\end{array}$ & $\begin{array}{l}\text { Theorizing and situational inquiry and } \\
\text { continual interplay between these. }\end{array}$ & $\begin{array}{l}\text { Different cyclical models exist } \\
\text { with emphasis on practical } \\
\text { problem solving. }\end{array}$ \\
\hline $\begin{array}{l}\text { Research } \\
\text { interest vs. } \\
\text { problem solving } \\
\text { interest }\end{array}$ & $\begin{array}{l}\text { Both interests guide situational inquiry. } \\
\text { Generated/furnished abstract knowledge } \\
\text { is instrumental for problem solving. } \\
\text { Situational knowledge (=empirical data) } \\
\text { is instrumental for theorizing. }\end{array}$ & $\begin{array}{l}\text { Both interests } r \text { are } \\
\text { acknowledged. Most emphasis } \\
\text { in descriptions on problem } \\
\text { solving. }\end{array}$ \\
\hline Field of study & Practices. & Situations (wholes). \\
\hline $\begin{array}{l}\text { Use of pre- } \\
\text { knowledge }\end{array}$ & $\begin{array}{l}\text { Practical theories and methods can } \\
\text { inform the situational inquiry. }\end{array}$ & $\begin{array}{l}\text { Inductive as well as theory- } \\
\text { informed approaches can be } \\
\text { used. }\end{array}$ \\
\hline $\begin{array}{l}\text { Different types } \\
\text { of knowledge }\end{array}$ & $\begin{array}{l}\text { A differentiation into situational vs. } \\
\text { abstract knowledge clearly related to the } \\
\text { activities of situational inquiry and } \\
\text { theorizing. }\end{array}$ & $\begin{array}{l}\text { Local/empirical and theoretical } \\
\text { knowledge. }\end{array}$ \\
\hline $\begin{array}{l}\text { Collaboration } \\
\text { between } \\
\text { researchers and } \\
\text { practitioners }\end{array}$ & $\begin{array}{l}\text { Can vary dependent on combinations of } \\
\text { different purposes and interests. }\end{array}$ & Demanded, but can vary. \\
\hline $\begin{array}{l}\text { Relations } \\
\text { between } \\
\text { different } \\
\text { research } \\
\text { orientations }\end{array}$ & $\begin{array}{l}\text { Encompassing view. PR can be } \\
\text { conducted as action research, design } \\
\text { research, evaluation research, case } \\
\text { studies or other approaches. }\end{array}$ & $\begin{array}{l}\text { Action research may be } \\
\text { combined with other } \\
\text { approaches e.g. design research. }\end{array}$ \\
\hline $\begin{array}{l}\text { Contribution to } \\
\text { local practice }\end{array}$ & $\begin{array}{l}\text { Different kinds of interventions } \\
\text { (diagnosis, design proposals, } \\
\text { implementation of changes/artefacts) } \\
\text { dependent on agreements between } \\
\text { researchers and practitioners. }\end{array}$ & $\begin{array}{l}\text { Implementation of changes } \\
\text { based on diagnosis and action } \\
\text { plans. }\end{array}$ \\
\hline $\begin{array}{l}\text { Contribution to } \\
\text { general practice }\end{array}$ & $\begin{array}{l}\text { Mandatory to be done according to PR } \\
\text { definition. Different kinds of } \\
\text { contributions (practical theories, generic } \\
\text { models, methods). }\end{array}$ & $\begin{array}{l}\text { Optional, not mandatory (not } \\
\text { stated as a demand in } \\
\text { definitions of AR). }\end{array}$ \\
\hline
\end{tabular}

Table 1 Practice research and action research compared 
Even if there is a continual interplay between theorizing and empirics in AR, these activities and their distinct properties should not be blurred in ways that make these differences collapse. The focus on local practices in AR approaches should be accompanied by a complementary focus on general practice. The generation of abstract knowledge should not only have research community as the target group. The abstract knowledge should be useful for general practice. The conduct of AR should be informed by needs and problems of the local operational practice as well as of general practice.

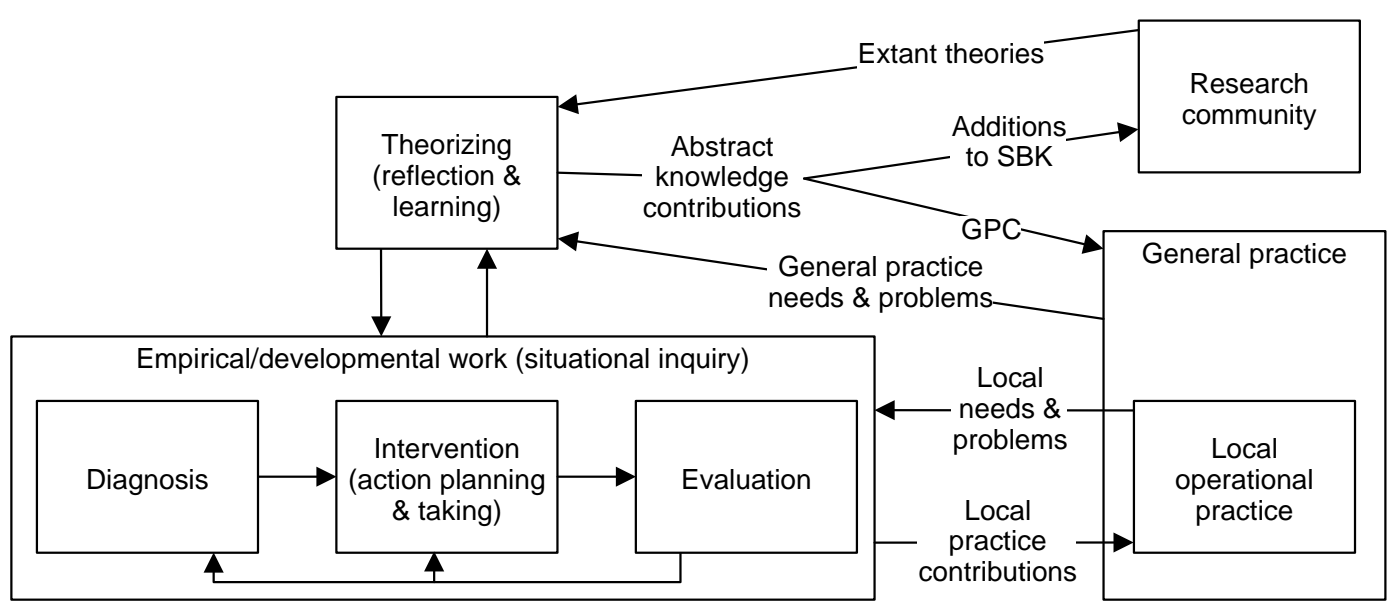

Figure 7 A refined view of action research based on practice research views and concepts

\section{EMPIRICAL ILLUSTRATIONS}

Two empirical illustrations will be given below. The purpose of these case accounts is to illustrate practice research and action research and their similarities and differences. There are two cases from research in e-government; one in taxation and one in the social welfare sector.

\section{A taxation case}

This study concerns a taxation e-service. Since several years, there exist an e-service for companies to declare VAT and staff taxes every month. This e-service ran parallel with an old routine consisting of a paper form declaration. The National Taxation Agency had hoped that the e-service should have been very popular and that most companies would use this type of communication medium instead of the paper form. However, after several years, there were only about one third of the companies that used the e-service. The rest used the paper form. The Taxation Agency had conducted several investigations (through questionnaires) in order to inquire why more companies did not use the eservice.

The National Taxation Agency participated in a larger research project concerning methods for service development. They asked the researchers to study this taxation e-service in order to obtain a better understanding of this partial failure. An evaluation study was initiated by one researcher (this author) in the research team. A thorough investigation was done comparing different service alternatives; the e-service and the paper form and different variants within these. It was necessary to disclose and model the two interconnected workpractices of the companies' accounting routines and the processing of taxation information at the Taxation Agency. An inter-organisational service modelling was conducted. This service modelling was made from a specific theoretical perspective 
which was labelled socio-instrumental (Goldkuhl, 2009). The idea was to investigate affordances in the services and service pre-conditions 1) at both parties, 2) of both positive and negative kinds and 3) of both socio-communicative and techno-instrumental character. This analysis revealed not yet known problems with the different service alternatives. New insights arise especially concerning the lack of integration with the accounting systems at the companies and also some deficiencies in the e-service. A diagnosis report was written with the Taxation Agency as the main target group. This report is one input for considering different alternative measures for the Taxation Agency.

The taxation study was a PR study, but it was not an AR study. It was limited to an evaluation study. Being an AR study it should include proposals for changes (perhaps both IT redesigns and organisational improvements) as well as more close cooperation between researchers and practitioners. The direct evaluation of the two service alternatives should be seen as a situational inquiry in terms of PR.

The evaluation case was one empirical part in a research development of service modelling methods. There existed some methods prior to the evaluation. Other method components (concepts, notations) were developed during the evaluation process due to discovered needs and generated insights. These new methods thus emerged as responses to practical and conceptual needs. The development of these new concepts and notations was carried out in a "theorizing" activity supporting the service evaluation.

The evaluation of the e-service had one function of a testbench of methods for modelling e-services in context. After the evaluation, experiences from the e-service modelling have been reported (to the research community and to general practice). These experiences have also been fed into further development of methods for e-service design and evaluation (Goldkuhl \& Röstlinger, 2007). The evaluation was also very generative concerning an enhanced conceptualization of e-services as coservices and socio-instrumental pre-conditions for e-service use (Goldkuhl, 2009). These are examples of theorizing occurring both during and after the evaluation process (situational inquiry).

\section{A social welfare case}

This case study is from a project working with IT development in the social welfare sector. Several municipalities participated in the project in order to develop joint IT solutions. These solutions comprise both an e-service application for clients and a multi-query application for collecting information about clients from state agencies. One impetus for starting the project was a new regulation that gives the municipalities better possibilities to obtain information about clients. The handling of client information within the public sector is severely restricted due to data protection regulations. The new regulation makes it easier for municipalities to obtain information about the clients' economic situation. A multi-query application was developed and launched to the participating municipalities. Information can now, on demand, be transferred electronically and immediately from state agencies (like the Social Insurance Agency and the Board for Study Support) to the social welfare offices at the municipalities. This communication was earlier mainly conducted through telephone calls and a slow batch query application.

Two researchers (one of them the author) participated in this project as action researchers and design researchers. The integration of action research and design research in this project has been described in Goldkuhl (2012). The roles of the two participating researchers have been to actively conduct development tasks (like process modelling, information modelling, user-interface design, XML schema design, program coding, testing and deployment) besides traditional research tasks like data collection and analysis. The original research interest was to study inter-organisational development of e-infrastructure in e-government. 
This research is an example of practice research that is also action research. The work in the development project followed a traditional problem solving model of AR: An initial diagnosis was conducted, mainly through process modelling, conceptual modelling, legal analysis and studies of existing legacy systems in the social welfare offices. Design proposals were elaborated for a new IT artefact (the multi-query application) and for revised work processes. Lo-fi prototypes of the userinterface design and new process models were produced, which corresponds to action planning in the model of Susman \& Evered (1978); figure 2 above. The next step (action taking) comprised coding, testing and deploying the new artefact. After implementation in several municipal welfare offices, evaluations of use have been conducted.

This has been a typical AR project with intense collaboration between researchers and practitioners. Several ideas from the researchers and other concepts from prior research have been used in the design process. A particular research interest was to study principles for e-infrastructure evolution (e.g. Hanseth \& Lyytinen, 2010; Markus et al, 2006). During the process we also formulated design principles about conceptual, processual and legal transparency. The formulation of these design principles was performed by the two researchers when reflecting on the design process. This reflection and formulation of design principles were dealt with in a "theorizing" activity that supported the design process in the situational inquiry. These different design principles guided the design of the multi-query application.

The design case (i.e. the situational inquiry) has produced a lot of empirical data which are used in theorizing. The theoretical analysis has generated several important insights about legal issues, interoperability and e-infrastructure evolution in e-government.

\section{Case comparison}

The two cases are both good examples of practice research. They comprise both local practice contributions and the generation of abstract knowledge aimed for general practice and research community. The taxation study is not an AR study. It is restricted to an evaluation study. There are no changes implemented as a result of this study so far. The level of collaboration was rather low. The social welfare case is a typical AR project. This case is also an example of design research. In table 2 there is a comparison between the two cases. It can be seen that the two cases fulfil the demands of what counts as practice research. From the comparison a variation between the two cases as practice research can also be seen.

\section{CONCLUSIONS}

This paper has contributed with a conceptual inquiry into action research leading to identification of several (partially unresolved) issues concerning such an approach. There are several obscurities and ambiguities within AR that need to be resolved. These identified issues have informed the articulation of practice research, which is another important contribution of this paper. Practice research has been described concerning its two main activities (theorizing and situational inquiry) and its contributions to different target groups (local practice, general practice and research community). The conceptualisation of PR can be used to clarify issues of AR. A comparison has also been made between $\mathrm{AR}$ and $\mathrm{PR}$ in order to reveal resemblances and differences. This comparison has also clarified that AR can be seen as a special kind of practice research. 


\begin{tabular}{|c|c|c|}
\hline & Taxation case & Social welfare case \\
\hline Type of research & $\begin{array}{l}\text { Practice research as evaluation } \\
\text { research. }\end{array}$ & $\begin{array}{l}\text { Practice research as combined } \\
\text { action research \& design research. }\end{array}$ \\
\hline $\begin{array}{l}\text { Researcher role and } \\
\text { collaboration }\end{array}$ & $\begin{array}{l}\text { An independent researcher study. } \\
\text { No active involvement of } \\
\text { practitioner in the study. }\end{array}$ & $\begin{array}{l}\text { Collaborative design between } \\
\text { researchers, IT designer and } \\
\text { social welfare officers. }\end{array}$ \\
\hline $\begin{array}{r}\text { solving } \\
\text { (practical }\end{array}$ & $\begin{array}{l}\text { Knowledge needed why an e- } \\
\text { service was not sufficiently used. }\end{array}$ & $\begin{array}{l}\text { New legal conditions gave a } \\
\text { window of opportunity for new } \\
\text { IT-based inter-organisational } \\
\text { information transfer. }\end{array}$ \\
\hline Studied practices & $\begin{array}{l}\text { Taxation practice. } \\
\text { Parts of companies' accounting } \\
\text { practices. } \\
\text { E-service evaluation practice. }\end{array}$ & $\begin{array}{l}\text { Municipal social welfare } \\
\text { practices. } \\
\text { State agencies' practices of } \\
\text { handling client information. } \\
\text { Practices for design of } \\
\text { e-infrastructure. }\end{array}$ \\
\hline $\begin{array}{ll}\text { Local } & \text { practice } \\
\text { contribution } & \end{array}$ & $\begin{array}{l}\text { Diagnosis of an e-service } \\
\text { (use vs. non-use). }\end{array}$ & $\begin{array}{l}\text { A new IT artefact, with designed } \\
\text { new work processes based on } \\
\text { diagnosis/modelling of current } \\
\text { situation. }\end{array}$ \\
\hline Research interests & 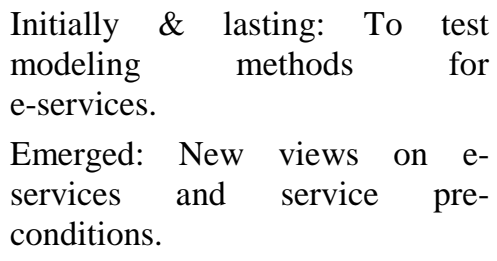 & $\begin{array}{l}\text { Initially \& lasting: To study } \\
\text { e-infrastructure development in e- } \\
\text { government. } \\
\text { Emerged: Design principles about } \\
\text { transparency. }\end{array}$ \\
\hline $\begin{array}{l}\text { Use of prior abstract } \\
\text { knowledge }\end{array}$ & $\begin{array}{l}\text { Socio-instrumental perspective on } \\
\text { e-services. Initial methods for e- } \\
\text { service modelling. }\end{array}$ & $\begin{array}{l}\text { Methods for process and } \\
\text { conceptual modelling. Design } \\
\text { principles for e-infrastructure } \\
\text { development. }\end{array}$ \\
\hline $\begin{array}{l}\text { Emergence of new } \\
\text { abstract knowledge }\end{array}$ & $\begin{array}{l}\text { New concepts and methods for e- } \\
\text { service modelling. }\end{array}$ & $\begin{array}{l}\text { Design principles about different } \\
\text { kinds of transparency in IT } \\
\text { artefacts }\end{array}$ \\
\hline $\begin{array}{l}\text { End products aimed } \\
\text { for general practice } \\
\text { and } \\
\text { community }\end{array}$ & $\begin{array}{l}\text { A new method package for } \\
\text { e-service modelling. } \\
\text { A developed definition of } \\
\text { e-services. }\end{array}$ & $\begin{array}{l}\text { New knowledge on legal issues, } \\
\text { interoperability and e- } \\
\text { infrastructure evolution in } \\
\text { e-government. }\end{array}$ \\
\hline
\end{tabular}

Table 2 Comparison of two practice research cases

The articulation of practice research should not at all be seen as a rejection of action research or neglecting the importance of this research approach. On the contrary, AR should be acknowledged for its contribution to local practices and its use of practical problem solving as a catalyst for the generation of scientific knowledge. The needs for the articulation of practice research can partially be found in some unresolved issues concerning AR described above. Baskerville \& Myers (2004) state 
that the paradigmatic foundations of AR can be found in pragmatism; cf. also Oquist (1978). However, the full implications of this pragmatist foundation have not been made. Practice research should be seen as an approach to bring pragmatism a step further in concrete research. Practice research is based on one pragmatist pillar to improve practice through knowledge (Dewey, 1938). This means not only through direct intervention into local practices, but more importantly a contribution to general practice through scholarly writing. Practice research rests also on a second pragmatist pillar that conceives the empirical field as a set of interconnected practices (e.g. Schatzki et al, 2001).

The title of this paper "From action research to practice research" should not be interpreted as a quest to move away from AR in the direction of PR. Action research should be preserved, but at the same time be further developed through the aid of this practice research articulation. "From action research to practice research" should be interpreted in the following way: Action research with 1) its fundamental pragmatist properties and 2) its unresolved issues and needs for clarification have contributed to the articulation of practice research. This means that this paper has made contributions to both the clarification of action research and to the articulation of practice research. This should also be seen as an important contribution to further development of qualitative research in information systems.

There are of course needs for further research of both conceptual and empirical kind concerning the application and development of AR and PR. This should comprise the study of not only action research as practice research, but also other forms of PR as design research and evaluation research.

\section{REFERENCES}

Argyris C, Putnam R, McLain Smith D (1985) Action science. Concepts, methods and skills for research and intervention, Jossey Bass, San Francisco

Avison D, Baskerville R, Myers M (2001) Controlling action research projects, Information Technology \& People, Vol 14, No 1 p 28-45

Baskerville R (1997) Distinguishing action research from participative case studies, Journal of Systems and Information Technology, Vol 1 (1), p 24-43

Baskerville R (1999) Investigating information systems with action research, Communication of AIS, Vol 2

Baskerville R, Myers M (2004) Special issue on action research in information systems: making IS research relevant to practice - foreword, MIS Quarterly, Vol 28 (3), p 329-335

Baskerville R, Pries-Heje J (1999) Grounded action research: a method for understanding IT in practice, Accounting, Management \& Information Technology, Vol 9, p 1-23

Baskerville R, Wood-Harper T (1998) Diversity in information systems action research methods, European Journal of Information Systems, Vol 7, p 90-107

Benbasat I, Zmud R W (1999) Emprical research in information system research: The practice of relevance, MIS Quarterly, Vol 23 (1), p 3-16

Bleicher J (1980) Contemporary hermeneutics. Hermeneutics as method, philosophy and critique, Routledge \& Kegan Paul, London

Blum F (1955) Action research - A scientific approach?, Philosophy of Science, Vol 22 (1), pp 1-7 
Cassell C, Johnson P (2006) Action research: Explaining the diversity, Human Relations, Vol 59 (6), p 783-814

Chandler D, Torbert B (2003) Transforming inquiry and action. Interweaving 27 flavors of action research, Action Research, Vol 1 (2), p 133-152

Checkland P (1991) From framework through experience to learning: The essential nature of action research, in Nissen H-E, Klein H, Hirschheim, R (Eds, 1991) Information systems research: Contemporary approaches and emergent traditions, North-Holland, Amsterdam

Chiasson M, Germonprez M, Mathiassen L (2009) Pluralist action research: a review of the information systems literature, Information Systems Journal, Vol 19 (1), p 31-54

Cole R, Purao S, Rossi M, Sein M (2005) Being Proactive: Where Action Research meets Design Research, Proceedings of the Twenty-Sixth International Conference on Information Systems, Las Vegas, p 325-336

Cronen V (2001) Practical theory, practical art, and the pragmatic-systemic account of inquiry, Communication theory, Vol 11 (1), p 14-35

Cronholm S, Goldkuhl G (2004) Conceptualizing Participatory Action Research - Three Different Practices, Electronic Journal of Business Research Methods, Vol 2 (2)

Cuff EC, Payne GCF (Ed, 1979) Perspectives in sociology, George Allen \& Unwin

Davenport T, Markus L (1999) Rigor vs. relevance revisited: A response to Benbasat and Zmud, MIS Quarterly, Vol 23 (1), p 19-23

Davison R M, Martinsons M G, Kock N (2004) Principles of canonical action research, Information Systems Journal, Vol 14, p 65-86

Dewey J (1938) Logic: The theory of inquiry, Henry Holt, New York

Elden M (1983) Democratization and Participative Research in Developing Local Theory, Journal of Occupational Behaviour, Vol 4 (1), p 21-33

Elden M, Crisholm (1996) Emerging Varieties of Action Research, Human Relations, Vol 46 (2), p 121-142

Gherardi S (2000) Practice-Based Theorizing on Learning and Knowing in Organizations, Organization, Vol 7 (2), p 211-223

Gherardi S (2009) The Critical Power of the 'Practice Lens', Management Learning, Vol. 40 (2), p $115-128$

Goldkuhl G (2008) Practical inquiry as action research and beyond, in Proceedings of the 16th European Conference on Information Systems, Galway

Goldkuhl G (2009) Socio-instrumental service modelling: An inquiry on e-services for tax declarations, in Persson A, Stirna J (Eds. 2009) PoEM 2009, LNBIP 39, pp. 207-221, Springer, Berlin

Goldkuhl G (2011) The research practice of practice research: theorizing and situational inquiry, Systems, Signs \& Actions, Vol 5 (1), p 7-29

Goldkuhl G (2012) Pragmatism vs. interpretivism in qualitative information systems research, European Journal of Information Systems, Vol 21 (2), p 135-146 
Goldkuhl G, Röstlinger A (2002) The practices of knowledge - investigating functions and sources, in Proc of the 3rd European Conference on Knowledge Management (3ECKM), Dublin

Goldkuhl G, Röstlinger A (2007) Clarifying Government - Citizen Interaction: From Business Action to Generic Exchange, in Proceedings of the 4th Scandinavian Workshop on e-Government, Örebro

Gregor S (2008) Building theory in a practical science, in Hart D, Gregor S (Eds, 2008) Information Systems Foundations: The role of design science, ANU E Press, Canberra

Gummesson E (1991) Qualitative methods in management research, Sage, Newbury Park

Hanseth O, Lyytinen K (2010) Design theory for dynamic complexity in information infrastructures: the case of building internet, Journal of Information Technology, Vol 25, 1-19

Heron J, Reason P (2001) The practice of co-operative inquiry: Research 'with' rather than 'on' people, in Reason P, Bradbury H (Eds, 2001) Handbook of action research, Sage, London

Hult M, Lennung S-Å (1980) Towards a definition of action research: a note and bibliography, Journal of Management Studies, Vol 17, p 241-250

Huxham C, Vangen (2003) Researching organizational practice through action research: Case studies and design choices, Organizational Research Methods, Vol 6 (3), p 383-403

Iivari J, Venable J (2009) Action research and design science research - Seemingly similar but decisively dissimilar, 17th European Conference on Information Systems, Verona

Israel B, Schurman S, Hugentobler M (1992) Conducting action research: Relationships between organization members and researchers, Journal of Applied Behavioral Science, Vol 28 (1), p 74-101

Järvinen P (2005) Action research as an approach in design science, the EURAM (European Academy of Management) Conference, Munich

Keen P G W (1991) Relevance and rigor in information systems research: Improving quality, confidence, cohesion and impact, in Nissen H-E, Klein H, Hirschheim, R (Eds, 1991) Information systems research: Contemporary approaches and emergent traditions, NorthHolland, Amsterdam

Lee A (1999) Rigor and Relevance in MIS Research: Beyond the Approach of Positivism Alone, MIS Quarterly, Vol 23, (1), p 29-33

Levina N, Vaast E (2006) Turning a community into a market: A practice perspective on information technology use in boundary spanning, Journal of Management Information Systems, Vol 22 (4), p 13-37

Ludema J, Cooperrider D, Barrett F (2001) Appreciative inquiry: The power of the unconditional positive question, in Reason P, Bradbury H (Eds, 2001) Handbook of action research, Sage, London

Lundin R, Wirdenius H (1990) Interactive research, Scandinavian Journal of Management, Vol 6 (2), p 125-142

Lyytinen K (1999) Empirical research in information systems: On the relevance of practice in thinking of IS research, MIS Quarterly, Vol 23, (1), p 25-27

Kemmis S, McTaggart R (2000) Participatory action research, in Denzin NK, Lincoln YS (Eds, 2000) Handbook of qualitative research, 2 ed, Sage, Thousands Oakes 
Klein G, Jiang J, Saunders C (2006) Leading the Horse to Water, Communications of AIS, Vol 20, Article 13

Kock N, (Ed. 2007) Information Systems Action Research. An Applied View of Emerging Concepts and Methods, Springer

Kock N, Gray P, Hoving R, Klein H, Myers M, Rockart J (2002) IS Research Relevance Revisited: Subtle Accomplishment, Unfulfilled Promise, or Serial Hypocrisy?, Communications of AIS, Vol 8, pp 330-346

Kock N, Lau F (2001) Information Systems Action Research: Serving Two Demanding Masters, Information Technology \& People, Vol 14 (1), p 6-11

Lau F (1997) A review on the use of action research in information systems studies, In Lee A, Liebenau J, DeGross J (Eds, 1997), Information Systems and Qualitative Research, Chapman \& Hall, London

Lewin K (1947) Frontiers in Group Dynamics II. Channels of group life; social planning and action research, Human Relations, Vol 1 (2), pp. 143-153

McKay J, Marshall P (2001) The dual imperatives of action research, Information Technology \& People, Vol 14 (1) p 45-59

McKay J, Marshall P (2002) Action Research: a Guide to Process and Procedure, in Proc of the European Conference on Research Methods in Business \& Management, University of Reading

McKay J, Marshall P (2006) Driven by two masters, serving both: The interplay of problem solving and research in information systems action research projects, in Kock N, (Ed. 2007) Information Systems Action Research. An Applied View of Emerging Concepts and Methods, Springer

Markus L, Steinfield C, Wigand R, Minton G (2006) Industry-wide information systems standardization as collective action: the case of the U.S. residential mortgage industry, MIS Quarterly, Vol 30, p 439-465

Mathiassen L (2002) Collaborative practice research, Information Technology \& People, Vol 15 (4), p 321-345

Metcalfe M (2008) Pragmatic inquiry, Journal of the Operational Research Society, Vol 59, p 10911099

Miettinen R, Samra-Fredericks D, Yanow D (2009) Re-Turn to Practice: An Introductory Essay, Organization Studies, Vol 30 (12), p 1309-1327

Mumford E (2001) Advice for an action researcher, Information Technology \& People, Vol 14 (1), pp $12-27$

Nielsen P A (2007) IS action research and its criteria, in Kock N, (Ed. 2007) Information Systems Action Research. An Applied View of Emerging Concepts and Methods, Springer

Oquist P (1978) The epistemology of action research, Acta Sociologica, Vol 21 (2), pp 143-163

Orlikowski W J (2000) Using technology and constituting structures: a practice lens for studying technology in organizations, Organization Science, Vol 11 (4), pp 404-428

Parks P (2001) Knowledge and participatory research, in Reason P, Bradbury H (Eds, 2001) Handbook of action research, Sage, London 
Pasmore W A, Stymne B, Shani A B, Mohrman S A, Adler N (2008) The Promise of Collaborative Management Research, in Shani A B, Mohrman S A, Pasmore W A, Stymne B, Adler N (Eds, 2008) Handbook of Collaborative Management Research, Sage, Los Angeles

Peters M, Robinson V (1984) The origins and status of action research, Journal of Applied Behavioral Science, Vol 20 (2), pp 113-124

Rapoport R N (1970) Three dilemmas in action research, Human Relations, Vol 23 (6), p 499-513

Reason P (1999) Integrating action and reflection through co-operative inquiry, Management Learning, Vol 30 (2), p 207-226

Reckwitz A (2002) Toward a Theory of Social Practices. A Development in Culturalist Theorizing, European Journal of Social Theory, Vol 5 (2), p 243-263

Revans R W (1982) What is action learning?, Journal of Management Development, Vol. 1 (3), P 6475

Rosemann M, Vessey I (2008) Toward improving the relevance of information systems research to practice: the role of applicability checks, MIS Quarterly, Vol 32 (1), p 1-22

Schatzki T R (1996) Social practices. A Wittgensteinian approach to human activity and the social, Cambridge University Press

Schatzki T R, Knorr Cetina K, von Savigny E (Eds, 2001) The practice turn in contemporary theory, Routledge, London

Schein E (2001) Clinical inquiry/research, in Reason P, Bradbury H (Eds, 2001) Handbook of action research, Sage, London

Scollon R (2001) Mediated discourse. The nexus of practice, Routledge, London

Sein M, Henfridsson O, Purao S, Rossi M, Lindgren R (2011) Action design research, MIS Quarterly, Vol 35 (1), p 37-56

Stevenson C (2005) Practical inquiry/theory in nursing, Journal of Advanced Nursing, Vol 50 (2), 196-203

Strauss A, Corbin J (1998) Basics of qualitative research. Techniques and procedures for developing Grounded Theory, $2^{\text {nd }}$ edition, Sage, Newbury Park

Susman G I, Evered R D (1978) An assessment of the scientific merits of action research, Administrative Science Quarterly, Vol 23 (4) p 582-603

Torbert W (1999) The distinctive questions developmental action inquiry asks, Management Learning, Vol 30 (2) p 189-206

Vidgen R, Braa K (1997) Balancing interpretation and intervention in information systems research: The action case approach, in Lee AS, Liebenau J, DeGross J I (Eds, 1997) Information systems and qualitative research, Chapman \& Hall, London

Whittington R (2006) Completing the practice turn in strategy research, Organization Studies, Vol 27 (5), p 613-634 